\title{
Effects of Aqueous Extracts of Copaifera langsdorffii (Fabaceae) on the Growth and Reproduction of Spodoptera frugiperda (J. E. Smith) (Lepidoptera: Noctuidae)
}

\author{
RR SÂmia, RL de Oliveira, VF Moscardini, GA Carvalho
}

Lab de Ecotoxicologia, Depto de Entomologia, Univ Federal de Lavras, Lavras, MG, Brasil

\section{Keywords}

Biopesticide, fall armyworm, maize, pest management, plant extracts

\section{Correspondence}

Univ Federal de Lavras, Lavras, MG, 37200-

ooo, Brasil; rafasamia@gmail.com

Edited by Moisés J Zotti - UFPel

Received 22 July 2015 and accepted 5 April 2016

Published online: 3 May 2016

(C) Sociedade Entomológica do Brasil 2016

\begin{abstract}
Spodoptera frugiperda (J. E. Smith) (Lepidoptera: Noctuidae) is considered a pest of maize crops throughout the Western Hemisphere. We report on the effects of aqueous extracts of leaves and bark of Copaifera langsdorffii (Fabaceae) on the biology of $S$. frugiperda, as an alternative source of natural bioactive molecules for the sustainable management of this pest. Second instars were sprayed with aqueous extracts prepared with $5 \%(w / v)$ plant material and/or fed on an artificial diet containing extracts at a concentration equivalent to $0.25 \%(w / v)$ for 17 days. Both leaf and bark extracts of $C$. langsdorffii significantly reduced $S$. frugiperda food intake, feces, and larval weight and caused a delay in larval development. Additionally, C. langsdorffii-based extracts increased the oviposition period; induced morphological changes in the eggs, including deformation of the corium and malformation of the micropylar and aeropylar regions; and reduced egg viability. But, aqueous extracts of $C$. langsdorffii exhibited no negative effects on larval and pupal survival, duration of the pupal stage, survival of pupae, sex ratio, longevity, duration of pre-oviposition period, and female fecundity. Aqueous extracts of leaves and bark of C. langsdorffii are promising alternatives for the control of S. frugiperda in maize crops.
\end{abstract}

\section{Introduction}

Spodoptera frugiperda (J. E. Smith) (Lepidoptera: Noctuidae), the most important pest of maize in the Western Hemisphere, and especially in Brazil, can cause major damage to the crop at any time of the year with attendant economic consequences (Nagoshi et al 2007). Control is difficult, mainly because the caterpillar remains inside the cob, and typically involves the application of pesticides. The continual use of such chemicals may give rise to the selection of resistant insect populations (Yu \& McCord 2007), contamination of the environment, and toxic exposure to beneficial insects, animals, and humans.

The identification of novel compounds with significant insecticidal properties, but with reduced impact on the environment, has received a great deal of attention over the years (Motohiro \& Casida 2005, Sanchez-Bayo et al 2013). In this context, natural products arising from plant secondary metabolism are often presented as promising alternatives for the control of pests, as selection for resistant strains is less likely because these molecules typically have more complex structures than those of their synthetic counterparts (Rattan 2010). Numerous examples of plant-derived insecticides are available (Ogbuewu et al 2011, Chakradhar et al 2010, Baskar \& Ignacimuthu 2012), including many that have been isolated from leguminous species. Indeed, interest in members of Fabaceae as sources of natural insecticides has grown over the last few years as shown by the increased number of reports related to this field (Adeyemi 2010, Jayakumar 2012). 
Copaifera langsdorffii (Fabaceae), popularly known as copaiba, is distributed from northeastern Argentina to Venezuela. In Brazil, it is found throughout the country (Lorenzi \& Souza 2005). The oil resin of C. langsdorffii is extracted from the trunk, being widely used in popular medicine (Veiga \& Pinto 2002). Copaifera langsdorffii essential oil has been shown to be active against late third and early fourth instars of Aedes aegypti L. (Diptera: Culicidae), the vector of the dengue, chikunguya, and zika viruses (Prophiro et al 2012; Diagne et al 2015; Savage et al 2015). Essential oils and extracts of different parts of the plants have shown insecticidal properties and the potential to affect several fitness traits of number of chewing and sucking insects (Barbosa et al 2011, Alves et al 2012, França et al 2012).

Considering the extensive damage caused by S. frugiperda to maize crops, and the potential of C. langsdorffii as a source of natural insecticides, the present study aimed to evaluate the effects of aqueous extracts of the leaves and bark of $C$. langsdorffii on the biology of S. frugiperda.

\section{Material and Methods}

\section{Plant materials}

Leaf and bark samples of $C$. langsdorffii were collected at the campus of the Universidade Federal de Lavras (UFLA; Lavras, MG, Brazil) and transported to the Laboratory of Ecotoxicology (Department of Entomology, UFLA). A specimen of $C$. langsdorffii was authenticated and deposited in the Herbarium of the Biology Department at UFLA under catalogue no. 05437. Plant samples were dried in a forced-air oven at $40^{\circ} \mathrm{C}$ until constant weight and triturated separately using a knife mill. The powdered materials were transferred to glass containers, which were hermetically sealed and stored in the freezer at $-6^{\circ} \mathrm{C}$ until use.

\section{Preparation of extracts}

A preliminary test performed with aqueous extracts of leaves and bark of $C$. langsdorffii revealed that those prepared with $5 \%(w / v)$ of powdered plant material were the most effective against $S$. frugiperda. On this basis, a stock solution was prepared by homogenizing the powder $(5 \mathrm{~g})$ with distilled water $(100 \mathrm{~mL})$ for $1 \mathrm{~min}$, following which the mixture was stored in a refrigerator for $24 \mathrm{~h}$ and subsequently filtered through muslin prior to use in the bioassays.
Insect rearing

A population of S. frugiperda was maintained at $25 \pm 2{ }^{\circ} \mathrm{C}$ under $70 \pm 10 \% \mathrm{RH}$ and a 14 -h photophase, according to Parra (2001).

\section{Experimental design and treatments}

The randomized experimental design comprised nine treatments (Fig 1) with five repetitions, each involving five second instars of S. frugiperda.

The diets employed in the bioassays were as follows: (i) diet $\mathrm{D}$ consisted of $300 \mathrm{~mL}$ of artificial diet prepared according to Greene et al (1976); (ii) diet L prepared by including $15 \mathrm{~mL}$ of the $5 \%(w / v)$ leaf extract for every $300 \mathrm{~mL}$ of diet, such that the final preparation contained a concentration equivalent to a $0.25 \%(w / v)$ leaf extract; (iii) diet B prepared as described in (ii) using $5 \%$ bark extract rather than leaf extract; and (iv) diet W prepared as described in (ii) except that leaf extract was replaced by distilled water in order to adjust the consistency to that of the experimental diets. In all cases, the diet was cooled gently to around $50^{\circ} \mathrm{C}$ before extracts were added, in order to avoid degradation of any heatsensitive components. All dietary preparations were allowed to gellify and had their fresh weigh determined. In order to estimate the natural loss of water, 20 samples of diet were allowed to dry to constant weight and then used to produce a regression line to correlate dry and wet weights.

Immediately prior to bioassay, second instars of S. frugiperda were placed in Petri dishes (15-cm OD) and sprayed directly with water or with $5 \%(w / v)$ leaf or bark extract using a Potter spray tower ${ }^{\circledR}$ (Burkard, Uxbridge, Middx, UK) operated at 15 psi to provide an even application (1.5 to $2.0 \mathrm{mg} / \mathrm{cm}^{2}$ ) of extract.

\begin{tabular}{|lll|}
\hline Treatment & Diet & Larvae \\
T1 (control) & D (artificial diet) & Sprayed with water \\
T2 (control) & W (diet D with added water) & Not subjected to spray \\
T3 (control) & W (diet D with added water) & Sprayed with water \\
T4 & D (artificial diet) & Sprayed with leaf extract 5\% \\
T5 & L (diet D containing leaf extract 0.25\%) & Not subjected to spray \\
T6 & L (diet D containing leaf extract 0.25\%) & Sprayed with leaf extract 5\% \\
T7 & D (artificial diet) & Sprayed with bark extract 5\% \\
T8 & B (diet D containing bark extract 0.25\%) & Not subjected to spray \\
T9 & B (diet D containing bark extract 0.25\%) & Sprayed with bark extract 5\% \\
\hline
\end{tabular}

Fig 1 Treatments employed in the bioassay involving leaf and bark extracts from Copaifera langsdorffii against Spodoptera frugiperda larvae. 


\section{Bioassays}

Plastic flasks containing diets $D, L, B$, or $W$ were inoculated individually with a single second instar of $S$. frugiperda that had either received no spray treatment or had been sprayed with water or extracts (Fig 1). Samples were incubated under the same conditions earlier described.

The effects of the extracts tested against $S$. frugiperda were assessed by monitoring larval survival (determined every $24 \mathrm{~h}$ ), larval weight gain (day 7 to day 17; sampled every 2 days), combined mass of larval feces at day 17, and amount of diet consumed ( $D, L, B$, and $W$ ) up to day 17 . Pupae were weighed $24 \mathrm{~h}$ after pupation and transferred to glass test tubes $(8.5 \times 2.0-\mathrm{cm}$ OD), which were then closed with cotton wool until adult emergence. Survival and duration of the pupal stage were also determined.

Adult insects were separated by sex and pooled according to their date of emergence. Five or more couples for each treatment were transferred to cylindrical polyethylene cages $(15 \times 10-\mathrm{cm} O D)$, each of which had been lined with filter paper to allow for egg deposition. Adults were fed with $10 \%$ honey solution. Oviposition was recorded daily, and egg viability was assessed using the second egg cluster. Eggs from the third cluster produced were placed in Karnovsky's fixative solution and stored at $4{ }^{\circ} \mathrm{C}$ for analysis by scanning electron microscopy (SEM). The duration of preoviposition and oviposition periods, as well as the sex ratio and adult longevity, were evaluated.

\section{SEM analysis}

Eggs fixed in Karnovsky's reagent was post-fixed with a solution of osmium tetroxide at $0.01 \mathrm{~g} / \mathrm{mL}$ in a $0.05-\mathrm{M}$ cacodylate buffer. Samples were then washed with distilled water and dehydrated with aqueous solutions of acetone in increasing concentrations $(25,50,75,90$, and $100 \%)$. Subsequently, samples were dried using the Critical Point Balzers CPD 030 apparatus. After drying, they were mounted on aluminum and gold stubs and brought to the SCD 050 Balzers evaporator to complete the preparation step. Samples were observed under a Leo Evo 40 SEM, using the Leo User Interface software to generate images (Carl Zeiss do Brasil, São Paulo, Brazil).

\section{Statistical analysis}

Food intake was corrected for water loss during the assay period (Cohen 2004). Data relating to food intake (FI), fecal excretion, duration of larval and pupal stages, mass and survival of pupae, duration of pre-oviposition and oviposition periods, number and viability of eggs, sex ratio, and longevity of adults were submitted to Shapiro-Wilk and Bartlett tests in order to verify normality of distribution and homoscedasticity, respectively. On confirmation of these assumptions, data were submitted to analysis of variance (ANOVA), and means were compared using the Scott-Knott test (Scott \& Knott 1974). In all tests, the level of statistical significance was set at $5 \%$.

Larval survival was assessed by survival analysis, while data relating to larval weight as a function of time were submitted to regression analysis using SAS for Windows (version 9.0; SAS Institute, Cary, NC, USA).

\section{Results}

Since no significant differences were observed between assays involving treatments $T_{1}, T_{2}$, and $T_{3}$, the results were expressed jointly as controls. The weight of $S$. frugiperda larvae increased throughout the 17-day period of bioassay in all treatments, but the amount of weight gain was dependent on the treatment (Table 1). At day 7 , the mean larval weight attained under all treatments were significantly lower $(F=3.725, p<0.01)$ than that recorded for the control. The most significant effects were observed with T5, T6, T8, and T9, in which larval weight was reduced by factors of 5, 4, 2.2, and 3.3, respectively, when compared with the control. From day 9 onward, the mean weights of larvae from treatments T4 to T9 were all lower than those of the control, and at day 17 , the mean weights were all significantly lower than that of the control with the single exception of T4. The linear regression functions representing the change of larval weight as a function of time according to the treatments applied are shown in Table 1.

Total Fl, fecal mass, and mean larval weight at the end of the larval stage (day 17) are depicted in Fig 2. Total FI values were significantly smaller for larvae exposed to treatments T5 to T9 compared with control $(F=17.215, p<0.01)$, whereas total fecal mass was significantly smaller for larvae that had been exposed to T4 to T9 $(F=15.571, p<0.01)$.

All treatments, except for T4 and T8, induced a significant delay in larval development in comparison with the control $(F=6.715, p<0.01 ;$ Fig 3$)$. In contrast, none of the applied treatments reduced larval $(F=2.092, p=0.0535$; Fig 4$)$ or pupal $(F=0.807, p=0.6126)$ survival nor did they induce a delay in pupal development $(F=0.942, p=0.4901)$. However, pupal weight was reduced in all treatments, except for T4 and T7 ( $F=6.050, p=0.0000$; Fig 5).

Reproductive variables could not be evaluated for T9 owing to the desynchronized emergence of adults, which impeded the matching of insect couples. The remaining treatments induced no significant alterations in the preoviposition period ( $F=1.873, p=0.0962$ ), although period of oviposition was significantly prolonged $(F=2.077, p=0.0652)$ in adults reared from T4, T6, and T8 (Fig 6). Sex ratio was not affected by treatments T4 to T8 $(F=0.946, p=0.4977)$ nor 
Table 1 Larval weight (mg) ( \pm standard error) of Spodoptera frugiperda exposed to different treatments with extracts from Copaifera langsdorffii

\begin{tabular}{|c|c|c|c|c|c|c|}
\hline \multirow[t]{2}{*}{ Treatment $^{a}$} & \multicolumn{6}{|c|}{ Days after initial exposure } \\
\hline & 7 & 9 & 11 & 13 & 15 & 17 \\
\hline $\begin{array}{l}\text { T1-T3 } \\
\quad(\text { control) }\end{array}$ & $20.0 \pm 7.0^{c}$ & $48.0 \pm 2.0^{A}$ & $124.0 \pm 4.0^{C}$ & $288.0 \pm 27.0^{C}$ & $583.0 \pm 19.0^{C}$ & $686.0 \pm 30.0^{\circ}$ \\
\hline $\mathrm{T} 4^{\mathrm{b}}$ & $11.0 \pm 2.0^{B}$ & $37.0 \pm 7.0^{A}$ & $86.0 \pm 14.0^{B}$ & $208.0 \pm 21.0^{B}$ & $402.0 \pm 56.0^{B}$ & $646.0 \pm 17.0^{C}$ \\
\hline$T 5^{c}$ & $4.0 \pm 1.0^{A}$ & $17.0 \pm 2.0^{A}$ & $42.0 \pm 2.0^{A}$ & $111.0 \pm 8.0^{A}$ & $219.0 \pm 20.0^{A}$ & $361.0 \pm 25.0^{A}$ \\
\hline $\mathrm{T} 6^{\mathrm{c}}$ & $5.0 \pm 1.0^{A}$ & $17.0 \pm 3.0^{\mathrm{A}}$ & $43.0 \pm 4.0^{A}$ & $115.0 \pm 8.0^{\mathrm{A}}$ & $206.0 \pm 7.0^{A}$ & $426.0 \pm 13.0^{A}$ \\
\hline$T 7^{d}$ & $11.0 \pm 1.0^{B}$ & $57.0 \pm 12.0^{\mathrm{A}}$ & $64.0 \pm 6.0^{A}$ & $154.0 \pm 17.0^{A}$ & $293.0 \pm 29.0^{A}$ & $507.0 \pm 40.0^{B}$ \\
\hline$T 8^{d}$ & $9.0 \pm 1.0^{A}$ & $40.0 \pm 14.0^{A}$ & $94.0 \pm 28.0^{B}$ & $183.0 \pm 24.0^{B}$ & $378.0 \pm 57.0^{B}$ & $541.0 \pm 42.0^{B}$ \\
\hline $\mathrm{Tg}^{\mathrm{c}}$ & $6.0 \pm 1.0^{A}$ & $28.0 \pm 16.0^{A}$ & $35.0 \pm 6.0^{A}$ & $86.0 \pm 16.0^{A}$ & $175.0 \pm 24.0^{A}$ & $342.0 \pm 56.0^{A}$ \\
\hline $\begin{array}{l}\text { Coefficient } \\
\text { of } \\
\text { variance } \\
\text { (\%) }\end{array}$ & 54.82 & 55.75 & 32.07 & 21.87 & 20.12 & 16.7 \\
\hline$p$ value & 0.002 & 0.044 & 0.000 & 0.000 & 0.000 & 0.000 \\
\hline
\end{tabular}

In each column, mean values followed by dissimilar uppercase capital letters are significantly different (ScottKnott test; $p<0.005$ )

${ }^{a}$ Details of treatments applied are presented in Fig 1.

${ }^{\mathrm{b}}$ Regression of larval weight versus time, $y=-0.5406+0.0685 x\left(R^{2}=0.9000, F=251.8672, p<0.0001\right)$

${ }^{c}$ Regression of larval weight versus time, $y=-0.3353+0.0392 x\left(R^{2}=0.8240, F=131.0824, p<0.0001\right)$

${ }^{d}$ Regression of larval weight versus time, $y=-0.3773+0.0464 x\left(R^{2}=0.8080, F=122.0737, p<0.0001\right)$ was adult longevity (male $F=1.138, p=0.3612$; female $F=1.138, p=0.3612$ ).

In comparison with the control, egg viability was reduced ( $F=2.859, p=0.0173$ ) by treatments T4, T5, T7, and T8 (Fig 7). The number of deformed eggs oviposited by females originating from larvae that had been exposed to T4, T5, T7, and T8, but not T6, was much higher in comparison with the control. Treatments $\mathrm{T} 4, \mathrm{~T} 5$, and $\mathrm{T} 7$ gave rise to eggs that

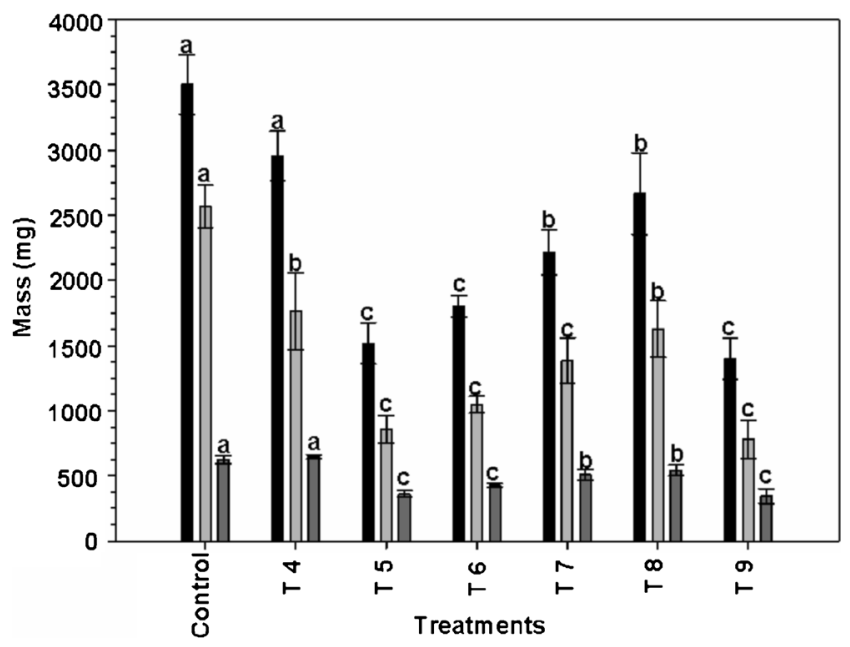

Fig 2 Mean values of food intake ( $F=17.215, p<0.01$ ), fecal mass ( $F=15.571, p<0.01)$, and larval weight $(F=20.112, p<0.01)$ after 17 days of the initial exposure to treatments (control and T4 to T9) described in Fig 1. Means following different letters are significantly different by the Scott-Knott test $(p<0.05)$. presented anomalies in the aeropylar regions, while treatment T8 induced malformations in the basal areas (Fig 8).

\section{Discussion}

The results presented herein demonstrate that aqueous extracts of the leaves and bark of $C$. langsdorffii induce negative

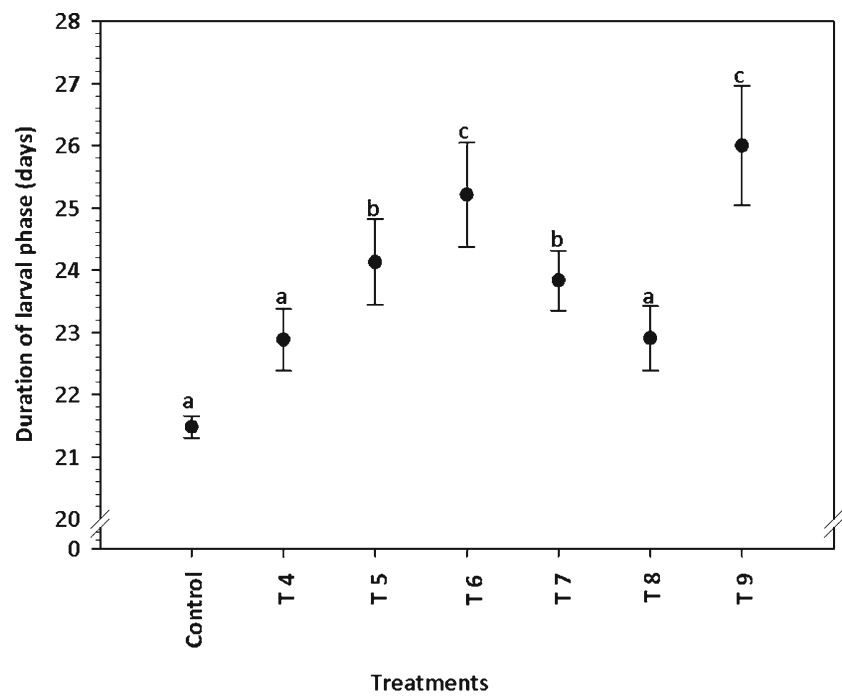

Fig 3 Larval developmental time $(F=6.715, p<0.01)$ of Spodoptera frugiperda exposed to treatments (control and T4 to T9) described in Fig 1. Means following different letters are significantly different by the Scott-Knott test $(p<0.05)$. 


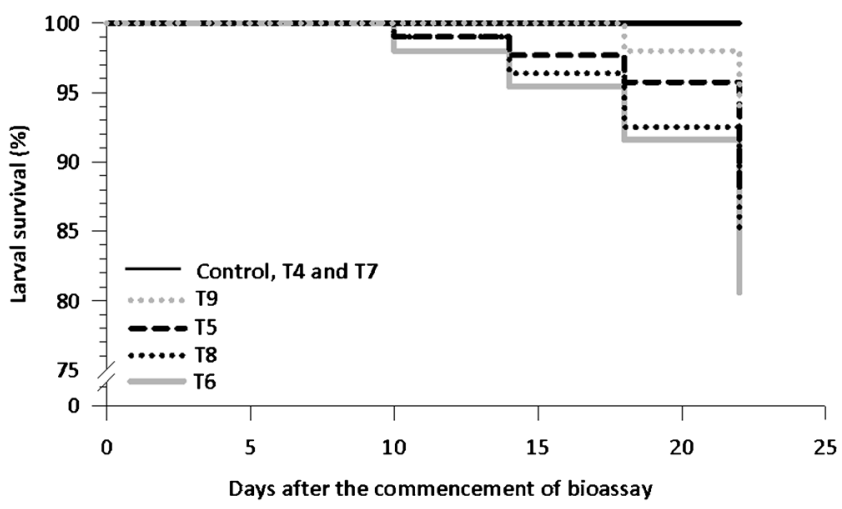

Fig 4 Larval survival (\%) of Spodoptera frugiperda after 17 days of exposure to treatments (control, T5, T6, T8, and T9) described in Fig 1. effects on the development of $S$. frugiperda when incorporated into the diet and/or sprayed onto second instars, indicating the presence of toxic components. Plants are known to accumulate a wide variety of compounds derived from secondary metabolism that can be produced in some tissues, translocate, and accumulate in other parts of plant, and many of them are thought to provide defense against herbivory (Taiz \& Zeiger 2009). According to Rodríguez \& Vendramim (1997), such molecules may be highly toxic to insects, affecting larva and pupa fitness traits, reducing female fecundity and fertility, and increasing mortality.

Differences in the bioactivities of aqueous extracts of leaves and bark of $C$. langsdorffii we demonstrated may be attributed to the differential capacities of these tissues to synthesize or accumulate toxic compounds. In an earlier investigation of the effects of methanol extracts of leaves, seeds, and fruit peel and pulp of $C$. langsdorffii on second instars of S. frugiperda, Alves et al (2012) found that leaf and peel

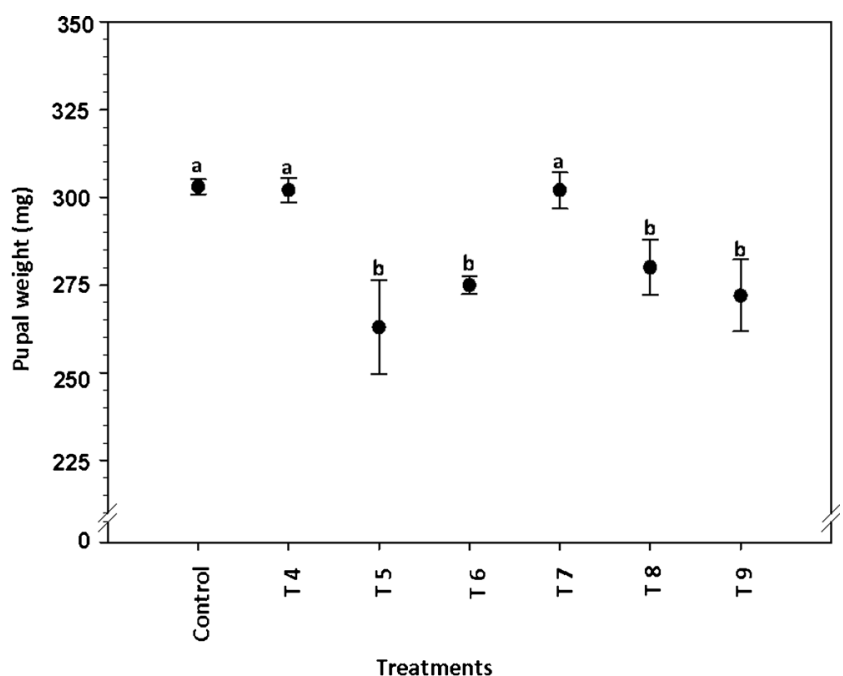

Fig 5 Pupal weight $(F=6.050, p<0.01)$ of Spodoptera frugiperda exposed to treatments (control and T4 to T9) described in Fig 1. Means following different letters are significantly different by the Scott-Knott test $(p<0.05)$.

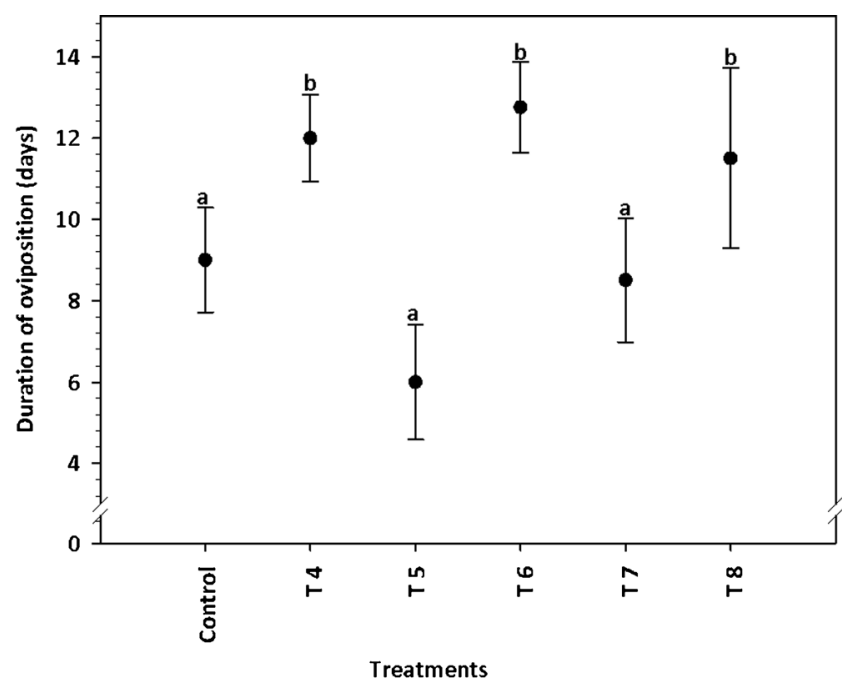

Fig 6 Duration of oviposition $(F=2.077, p=0.0652)$ of Spodoptera frugiperda exposed to treatments (control and T4 to T8) described in Fig 1. Means following different letters are significantly different by the Scott-Knott test $(p<0.05)$.

preparations were the most toxic. The bioactivities of aqueous extracts of Trichilia casaretti and T. pallens (Meliaceae) against S. frugiperda were also found to vary according to the part of the plant studied (Bogorni \& Vendramim 2005).

In the present study, reduced food intake, fecal mass, and larval weight were observed with treatments T5 to T9. This finding may be attributed to food deterrence activities associated with one or more of the components of the aqueous extracts such as proteinase inhibitors. In this context, novel trypsin inhibitors have been characterized in the seeds of C. langsdorffii (Krauchenco et al 2001, Silva et al 2001), and

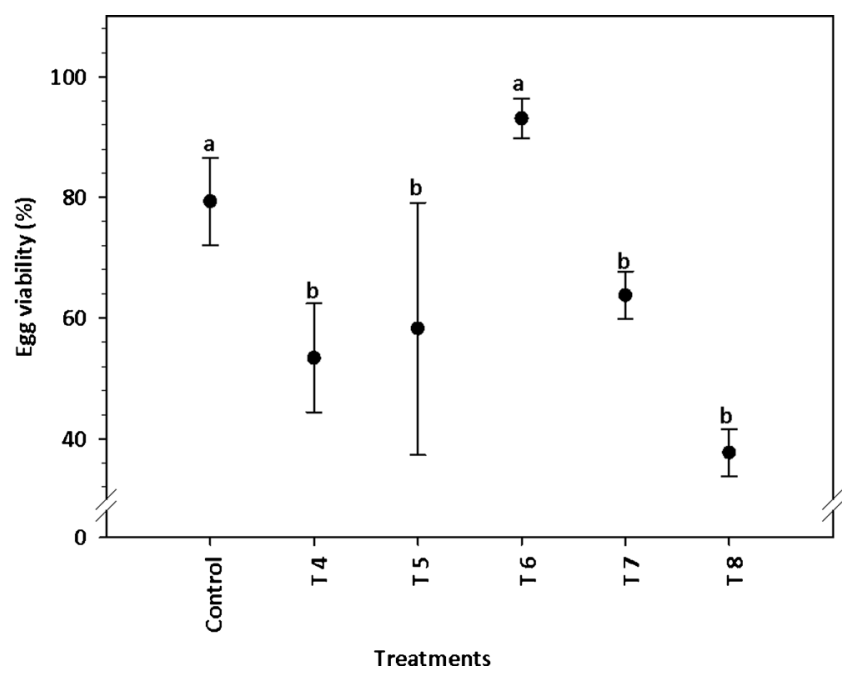

Fig 7 Egg viability (\%) $(F=2.859, p=0.0173)$ laid by females of Spodoptera frugiperda originating from larvae exposed to treatments (control and T4 to T8) described in Fig 1. Means following different letters are significantly different by the Scott-Knott test $(p<0.05)$. 
Fig 8 SEM micrographs of eggs of Spodoptera frugiperda laid by females originating from larvae exposed to treatments described in Fig 1, showing a control treatments-white arrow indicates normal aeropylar region, $\mathbf{b}$ treatment $\mathrm{T}_{4}-$ white arrow indicates abnormal aeropylar region, $\mathrm{c}$ treatment T5-white arrow indicates abnormal aeropylar region, $\mathbf{d}$ treatment $\mathrm{T} 6$ - white arrow indicates normal aeropylar region, e treatment $\mathrm{T} 7-$ white arrow indicates abnormal aeropylar zone, and $\mathbf{f}$ treatment T8-white arrow indicates deformed basal region.
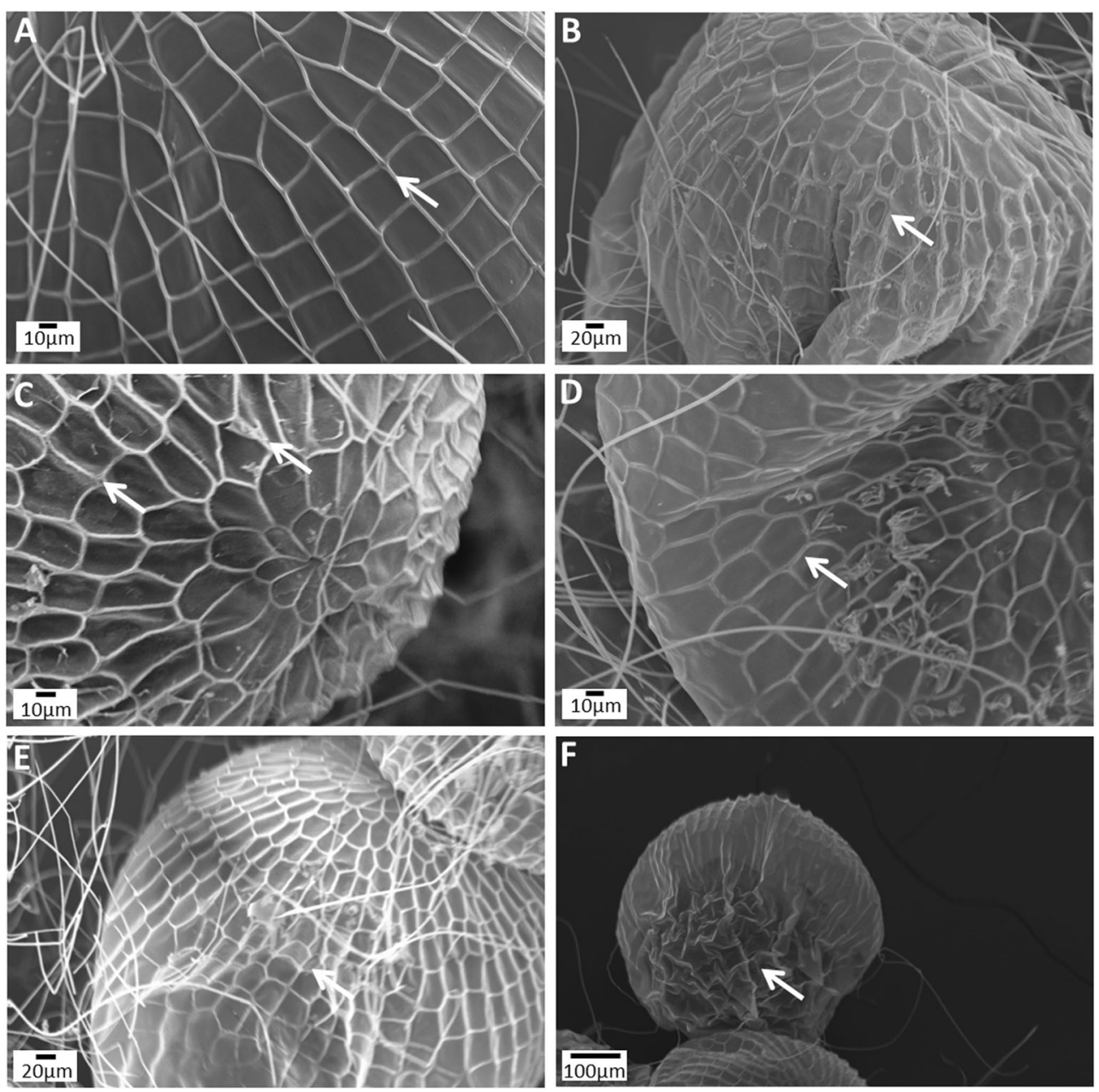

Alves et al (2012) reported that methanol extracts of leaves and fruit peel of $C$. langsdorffii exhibited a deterrence effect against $S$. frugiperda larvae in vivo and inhibited trypsin activity in vitro, providing founds that the aqueous extract of Copaifera leave may also contain these inhibitors. The observed prolongation of the larval stage following exposure to treatments $\mathrm{T5}, \mathrm{T} 6, \mathrm{~T} 7$, and T9 might be explained by the antibiotic activities of some components; the effect of which could be to hinder or prevent the metabolism of ingested food. Many compounds isolated from Fabaceae exhibit such properties and cause significant alterations on the development of $S$. frugiperda as the tannin fraction from Peltophorum dubium that caused restriction on food intake, prolongation of the larval phase, and increased mortality of larvae and pupae (Tirelli et al 2010). This effect probably results from the formation of complexes between tannins and digestive enzymes present in the gut of the insect, causing a reduction in the efficiency of protein digestion and, consequently, retardation of growth (Schoonhoven et al 2005).

In comparison with the control, no reductions in the weight of larvae were observed at the end of the larval stage (day 17) when leaf extracts of $C$. langsdorffii were applied exclusively by spraying, probably because the active components could not penetrate the body tegument because of their physical-chemical properties, e.g., low lipophilicity. The same was observed by Conceschi et al (2011) that reported that aqueous extracts of Azadirachta indica affected S. frugiperda larvae only when they were incorporated into the food, which, in this case, consisted of maize leaves.

No changes in pupal developmental time and survival were observed following exposure to $C$. langsdorffii extracts, although affecting several larval traits, similarly to the effects observed for leaf extracts of $T$. casaretti on $S$. frugiperda (Bogorni \& Vendramim 2005). Aqueous extracts of Talisia esculenta (Sapindaceae) or Sapindus saponaria (Sapindaceae) did not affect larval or pupal developmental times nor pupal viability of $S$. frugiperda, although larval weight was reduced (Santos et al 2008).

Adult longevity of $S$. frugiperda was not affected by the exposure to aqueous leaf or bark extracts of $C$. langsdorffii during its larval stage. However, the effects of these extracts in female reproduction indicate that extracts may have compounds that interfere with the assimilation and/or 
metabolism of nutrients, which may have led to nutrient deficiency and reduced energy pool with consequent damage to reproduction. Since nutritional status exerts a significant influence on the number and shape of ovarioles and on ovarian development in larvae, the lack or deficiency of nutrients may reduce the reproductive potential of female adults by diminishing the number and/or quality of eggs (Engelman 1998). According to Costa et al (2004), plant extracts may inhibit oviposition or reduce the number of eggs produced, and these effects may be associated with nutritional modifications induced by certain compounds.

In the present study, eggs oviposited by S. frugiperda females from larvae exposed to treatments $\mathrm{T}_{4}, \mathrm{~T}_{5}, \mathrm{~T} 7$, and T8 exhibited low viability, and this may be associated with nutritional deficiency induced by $C$. langsdorffii extracts during the larval stage. Such modifications may have had detrimental effects on embryogenesis, resulting in the morphological alterations observed in the eggs. Alves et al (2012) associated the low viability detected in eggs of S. frugiperda females fed on a diet containing methanol extracts of leaves and fruit peel of $C$. langsdorffii with ultrastructural modifications in the micropylar and aeropylar regions. Synthetic insecticides can also cause disturbances in protein metabolism, inducing negative effects on the embryogenesis of insects such as deposition of abnormal material in the corium since it is most composed by lipoproteins (Adamski et al 2005); Fila et al (2002) reported that larval exposure of Spodopeta exigua (Hübner) (Lepidoptera: Noctuidae) to the organophosphate fenitrothion induced egg morphological alterations in the micropylar and aeropylar regions similar to those observed in the present study, suggesting that once this product might have interfered with protein, synthesis could cause disturbance on the cement glands of adult females, consequently altering the deposition of the cement layer of the corium inducing the malformations observed.

In the present study, it was observed that larvae presenting lower $\mathrm{Fl}$ and weight gave rise to females that oviposited during a shorter period and laid eggs with lower viabilities. These results corroborate the findings of Alves et al (2012), who reported that methanol extracts of leaves and fruit peel of $C$. langsdorffii reduced the fertility and fecundity of S. frugiperda females, as well as the oviposition period and the fertility.

In summary, aqueous extracts of leaves and bark of C. langsdorffii had a negative effect on the biology of S. frugiperda when supplied in the diet and/or topically sprayed on the larvae, causing reduction of food intake, decrease in larval and pupal weight, prolongation of larval stage, and reduced fecundity. The bark extract was particularly damaging to egg viability. Aqueous extracts of leaves and bark of $C$. langsdorffii represent promising alternatives for the control of $S$. frugiperda, although the bioactive components, as well as their mode of action, remain to be elucidated.

Acknowledgments The authors wish to thank the Conselho Nacional de Desenvolvimento e Pesquisa (CNPq), Coordenação de Aperfeiçoamento de Pessoal de Ensino Superior (CAPES), and Fundação de Amparo à Pesquisa do Estado de Minas Gerais (FAPEMIG) for the financial support.

\section{References}

Adamski Z, Niewadzi M, Ziemnicki K (2005) Inheritance of chorionic malformations and insecticide resistance by Spodoptera exigua. J Appl Entomol 126:114-118

Adeyemi MMH (2010) The potential of secondary metabolites in plant material as deterrents against insect pests: a review. Afr J Pure Appl Chem 4:243-246

Alves DS, Carvalho GA, Oliveira DF, Sâmia RR, Villas-Boas MA, Carvalho GA, Côrrea AD (2012) Toxicity of copaiba extracts to armyworm (Spodoptera frugiperda). Afr J Biotechnol 11:6578-6591

Barbosa FS, Leite GLD, Alves SM, Nascimento AF, D'Avila VA, Costa CA (2011) Insecticide effects of Ruta graveolens, Copaifera langsdorffii and Chenopodium ambrosioides against pests and natural enemies in commercial tomato plantation. Acta Sci Agron 33:37-43

Baskar K, Ignacimuthu S (2012) Antifeedant, larvicidal and growth inhibitory effects of ononitol monohydrate isolated from Cassia tora L. against Helicoverpa armigera (Hub.) and Spodoptera litura (Fab.) (Lepidoptera: Noctuidae). Chemosphere 88:384-388

Bogorni PC, Vendramim JD (2005) Efeito subletal de extratos aquosos de Trichilia spp. sobre o desenvolvimento de Spodoptera frugiperda (J.E. Smith) (Lepidoptera: Noctuidae) em milho. Neotropical Entomol 34: 311-317

Chakradhar D, Narendra A, Nagaraju K (2010) Laboratory evaluation of grain protectant efficacy of different foliar extracts against maize weevil-Sitophilus zeamais (Motschulsky). Arch Phytopathol Plant Protect 43:1809-1818

Cohen AC (2004) Insect diets: science and technology. CRC Press, Boca Raton

Conceschi MR, Ansante TF, Mazzonetto F, Vendramim JD, Sossai VLM, Pizetta LC, Corbani RZ (2011) Efeito de extratos aquosos de Azadirachta indica e de Trichilia pallida sobre lagartas de Spodoptera frugiperda (J. E. Smith) (Lepidoptera: Noctuidae) em milho. BioAssay 6:1-6

Costa ELN, Silva RFP, Fiuza LM (2004) Efeitos, aplicações e limitações de extratos de plantas inseticidas. Acta Biol Leopold 26:173-185

Diagne CT, Diallo D, Faye O (2015) Potential of selected Senegalese Aedes spp. mosquitoes (Diptera: Culicidae) to transmit Zika virus. BMC Infect Dis 15:492

Engelman F (1998) Reproduction in insects. In: Huffaker CB, Gutierrez AP (eds) Ecological entomology. John Wiley, New York, pp 123-158

Fila K, Adamski Z, Ziemnicki K (2002) Exposure to fenitrothion causes malfunctions of Spodoptera exigua Hübn. (Lep., Noctuidae) eggs. J Appl Entomol 126:114-118

França SM, Oliveira JV, Esteves Filho AB, Oliveira CM (2012) Toxicity and repellency of essential oils to Zabrotes subfasciatus (Boheman) (Coleoptera, Chrysomelidae, Bruchinae) in Phaseolus vulgaris L. Acta Amazon 42:381-386

Greene GL, Leppla NC, Dickerson WA (1976) Velvetbean caterpillar: a rearing procedure and artificial medium. J Econ Entomol 69:487-488 
Jayakumar M (2012) Oviposition deterrent and adult emergence activities of some plant aqueous extracts against Callosobruchus maculatus F. (Coleoptera: Bruchidae). J Biopesticides 3:325-329

Krauchenco S, Silva JA, Nagem RA, Brandão Neto JR, Forrer VP, Carmona e Ferreira R, Macedo ML, Novello JC, Marangoni S, Polikarpov I (2001) Crystallization and preliminary X-ray diffraction analysis of a novel trypsin inhibitor from seeds of Copaifera langsdorffii. Acta Crystallogr D Biol Crystallogr 57:1316-1318

Lorenzi H, Souza VC (2005) Botânica sistemática: guia ilustrado para identificação das famílias de Angiospermas da flora brasileira, baseado em APG II. Instituto PlantarumNova Odessa, Nova Odessa, 637 p

Motohiro T, Casida JE (2005) Neonicotinoid insecticide toxicology: mechanisms of selective action. Rev Lit Arts Am 45:247-268

Nagoshi RN, Silvie P, Meagher RL, Lopez J, Machado V (2007) Identification and comparison of fall armyworm (Lepidoptera: Noctuidae) host strains in Brazil, Texas, and Florida. Ann Entomol Soc Am 100:394-402

Ogbuewu IP, Odoemenam VU, Obikaonu HO, Opara MN, Emenalom OO, Uchegbu MC, Okoli IC, Esonu BO, Iloeje MU (2011) The growing importance of neem (Azadirachta indica A. Juss) in agriculture, industry, medicine and environment: a review. Res J Med Plant 5:230-245

Parra JRP (2001) Técnicas de criação de insetos para programas de controle biologico (3rd edn) FEALQ. ESALO/FEALQ, Piracicaba, 134p

Prophiro JS, Silva MA, Kanis LA, Rocha LC, Duque-Luna JE, Silva OS (2012) First report on susceptibility of wild Aedes aegypti (Diptera: Culicidae) using Carapa guianensis (Meliaceae) and Copaifera sp. (Leguminosae). Parasitol Res 110:699-705

Rattan RS (2010) Mechanism of action of insecticidal secondary metabolites of plant origin. Crop Prot 29:913-920

Rodríguez HC, Vendramim JD (1997) Avaliação da bioatividade de extratos aquosos de Meliaceae sobre Spodoptera frugiperda (J. E. Smith). Rev Agric 72:305-318
Sanchez-Bayo F, Tennekes HA, Goka K (2013) Impact of systemic insecticides on organisms and ecosystems. In: Trdan S (ed) Insecticidesdevelopment of safer and more effective technologies. InTech, Croatia, pp 365-414

Santos WL, Freire MGM, Bogorni PC, Vendramim JD, Macedo MLR (2008) Effect of the aqueous extracts of the seeds of Talisia esculenta and Sapindus saponaria on fall armyworm. Braz Arch Biol Technol 51: 373-383

Savage HM, Ledermann JP, Yug L, Burkhalter KL et al (2015) Incrimination of Aedes (Stegomyia) hensilli Farner as an epidemic vector of Chikungunya virus on Yap Island, Federated States of Micronesia, 2013. Am J Trop Med Hyg 92:429-436

Schoonhoven LM, van Loon JJA, Dicke M (2005) Insect plant biology. Oxford University Press, New York, pp 101-127

Scott AJ, Knott M (1974) A cluster analysis method for grouping means in the analysis of variance. Biometrics 30:507-512

Silva JA, Macedo ML, Novello JC, Marangoni S (2001) Biochemical characterization and $\mathrm{N}$-terminal sequences of two new trypsin inhibitors from Copaifera langsdorffii seeds. J Protein Chem 20:1-7

Taiz L, Zeiger E (2009) Fisiologia vegetal (4th ed.) Ed. Artmed, Porto Alegre. 819p.

Tirelli AA, Alves DJ, Carvalho GA, Sâmia RR, Brum SS, Guerreiro MA (2010) Efeito de frações tânicas sobre parâmetros biológicos e nutricionais de Spodoptera frugiperda (Lepidoptera: Noctuidae). Ciênc Agrotec 34:1417-1424

Veiga VF, Pinto AC (2002) O gênero Copaifera L. Quim Nov. 25:273-286

Yu SJ, McCord E (2007) Lack of cross-resistance to indoxacarb in insecticide-resistant Spodoptera frugiperda (Lepidoptera: Noctuidae) and Plutella xylostella (Lepidoptera: Yponomeutidae). Pest Manag Sci 63:63-67 